\title{
PENGARUH PARAMETER LINGKUNGAN DAN PENEMPATAN POSISI MODUL TERHADAP LUARAN ENERGI PLTS MENGGUNAKAN SOLAR CELL 50 WP, 12 VOLT
}

\author{
Rusman Sinaga \\ Jurusan Teknik Elektro Politeknik Negeri Kupang \\ Jl. Adisucipto Po.Box.139 Penfui, Kupang 85361 NTT, Indonesia \\ aganis02@yahoo.com
}

\begin{abstract}
Abstrak: Kondisi geografis merupakan salah satu hambatan pemasokan energi listrik melalui jaringan PLN ke perdesaan di Indonesia, sehingga masih banyak rumah tangga yang belum menikmati layanan energi listrik. Sesuai kondisi klimatologi NTT yang mempunyai musim kemarau panjang, penggunaan Pembangkit Listrik Tenaga Surya (PLTS) dipandang potensial dikembangkan. Pemanfaatan PLTS listrik surya atap di NTT saat ini mencapai 10.751 unit, namun demikian, akhir-akhir ini pemakaian PLTS mengalami beberapa permasalahan yaitu PLTS tersebut sering tidak dapat berfungsi dengan baik dan beban lampu yang dipasang menghasilkan nyala yang kurang terang. Permasalahan ini diduga berkaitan dengan faktor-faktor lingkungan seperti suhu, iluminasi radiasi sinar matahari, kelembaban dan juga letak posisi penempatan modul sel surya terhadap bumi yang kurang tepat. Tujuan penelitian ini adalah untuk membuktikan pengaruh parameter lingkungan (suhu, iluminasi radiasi sinar matahari, kelembaban) dan penempatan posisi modul terhadap luaran energi PLTS. Metode yang digunakan adalah eksperimen dan deskriptif. Hasil penelitian diketahui bahwa iluminasi radiasi sinar matahari sangat berpengaruh terhadap luaran energi PLTS, Jika Iluminasi bertambah 1 Lux maka luaran energi akan bertambah 0.001 Wh dengan asumsi suhu konstan. Kelembaban tidak berpengaruh terhadap luaran energi PLTS dan pengaruh suhu hanya dapat terlihat pada siang hari. Penempatan modul PLTS tegak lurus dengan bumi menghasilkan luaran energi optimum
\end{abstract}

Kata Kunci: Luaran energi, Iluminasi radiasi sinar matahari, suhu, kelembaban

\section{PENDAHULUAN}

Sampai saat ini masih banyak dari anggota masyarakat di Indonesia, terutama yang berada di pedesaan yang belum merasakan layanan listrik. Hal ini terutama disebabkan oleh kesulitan keadaan geografis daerah tersebut sehingga tidak memungkinkan dijangkau oleh jaringan listrik yang disediakan oleh Perusahaan Listrik Negara (PLN). Di Propinsi Nusa Tenggara Timur dari 2.545 jumlah total desa, $1.456(57,21 \%)$ dari total desa masih belum mendapatkan aliran listrik PLN, 123 desa diantaranya yang tidak dapat dijangkau oleh PLN sudah dipasang Pembangkit Listrik Tenaga Surya (PLTS), (PT. PLN. Wilayah NTT, 2010).
Sesuai dengan kondisi klimatologi NTT yaitu mempunyai musim kemarau yang relatif panjang, penggunaan pembangkit listrik tenaga surya dipandang potensial dikembangkan di NTT. Sejak tahun 2000an, penggunaan PLTS sudah mulai dikembangkan di beberapa daerah di kabupaten Kupang, Kabupaten Timor Tengah Selatan (TTS), Kabupaten Timor Tengah Utara (TTU) dan Kabupaten Alor (Sinlae et al. 2004). Namun demikian akhirakhir ini penyediaan PLTS ini juga banyak dikeluhkan masyarakat dibeberapa daerah seperti yang terjadi di Kabupaten Alor belakangan ini. Menurut pengakuan salah seorang warga Desa Teluk Kenari, Kecamatan Mutiara Kabupaten Alor "Listrik Tenaga Surya 
menyala tetapi tidak terlalu terang, kalau awan mendung, listrik tidak bisa menyala, sementara jika panas terik, terangnyapun tidak berbeda jauh dari sekarang”. Ungkapan senada disampaikan oleh warga Desa Hulnani "Selama ini, pada siang hari PLTS berfungsi dengan baik. Kalau pada siang hari matahari sangat panas, maka malam harinya lisrik menyala terang, namun jika pada siang hari cuaca mendung listrik tidak berfungsi sama sekali”. Adanya beberapa keluhan yang dikemukakan oleh pemakai sel surya tersebut menimbulkan beberapa pertanyaan. Apakah benar kondisinya demikian dan jika benar dimanakah kekeliruan sehingga sel surya tersebut tidak dapat berfungsi dengan baik. Hal ini perlu diteliti untuk mencari permasalahan pokok dan menemukan alternatif solusinya. Tidak optimalnya penggunaan PLTS diduga berkaitan dengan faktor-faktor lingkungan seperti suhu, iluminasi radiasi sinar matahari, kelembaban (Soemarwoto O. 2004) dan juga letak posisi penempatan modul PLTS terhadap bumi yang kurang tepat sehingga mempengaruhi luaran energi PLTS.

Luaran energi sel surya yang dihasilkan dari PLTS dapat dipengaruhi oleh beberapa parameter lingkungan seperti suhu, iluminasi radiasi sinar matahari dan kelembaban baik pada pagi, siang maupun sore hari (Walery 2003). Luaran sel surya juga dapat dipengaruhi oleh letak posisi penempatan modul sel surya terhadap bumi (SHS 2010). Parameterparameter ini dapat mempengaruhi sukses tidaknya PLTS yang digunakan. Adanya keluhan-keluahan yang dikemukakan oleh pemakai PLTS di atas dapat dipengaruhi oleh faktor-faktor tersebut. Namun demikian, sejauh mana faktor-faktor tersebut mempengaruhi dapat diungkapkan melalui penelitian ini. Penelitian ini mengkaji pengaruh suhu, iluminasi radiasi sinar matahari, kelembaban dan posisi penempatan modul sel surya pada pagi, siang dan sore hari terhadap luaran energi sel surya. Selain itu diteliti pula pengaruh posisi penempatan modul terhadap luaran energi PLTS.
Kadir (1990), mengungkapkan bahwa perubahan suhu berpengaruh terhadap tegangan keluaran dari sel surya. Besarnya arus listrik yang diperoleh tergatung dari energi cahaya matahari yang mencapai sel-sel silicon modul sel surya dan tergantung juga dari luas permukaan modul tersebut. Djojonegoro (1992) menjelaskan lebih lanjud bahwa salah satu kendala pengembangan energi terbarukan di Indonesia antara lain kontiniutas penyediaan energi listrik rendah, karena sumberdaya energinya sangat bergantung pada kondisi alam yang perubahannya tidak menentu.

Pada penelitian ini pengaruh suhu, iluminasi radiasi sinar matahari, kelembaban, dan posisi penempatan modul sel surya pada pagi, siang dan sore hari terhadap luaran energi PLTS diteliti. Selain itu bagaimanakah dampak dari posisi penempatan modul PLTS tersebut terhadap energi yang dihasilkan PLTS juga diteliti. Secara khusus permasalahan yang dikaji dalam penelitian ini dapat dirumuskan sebagai berikut:

- Bagaimana pengaruh parameter lingkungan (suhu, iluminasi radiasi sinar matahari dan kelembaban) terhadap luaran energi PLTS.

- Seberapa besarkah pengaruh letak posisi penempatan modul sel surya terhadap besarnya luaran energi PLTS.

Tujuan penelitian ini adalah untuk membuktikan bagaimana pengaruh parameter lingkungan (suhu, iluminasi radiasi sinar matahari, kelembaban) dan penempatan posisi modul terhadap luaran energi PLTS. Hasil penelitian ini dapat diharapkan memberikan masukan kepada masyarakat pemakai PLTS, memberikan masukan kepada Pemerintah Daerah Tingkat II khususnya Kabupaten yang masyarakatnya menggunakan PLTS sehingga dapat memberikan penjelasan langsung kepada masyarakat pengguna PLTS tersebut, menambah teori pada mata kuliah Pembangkit Tenaga Listrik dan Pengelolaan Sumberdaya alam dan lingkungan dan juga merupakan aplikasi mata kuliah statistik. 


\section{BAHAN DAN METODA}

Bahan yang digunakan berupa modul PLTS dengan spesifikasi teknis sebagai berikut: Modul Solar Cell 50 WP / 12 V, Box Power Unit ( Batterey $70 \mathrm{AH} / 12 \mathrm{~V}$, Controller $10 \mathrm{~A} / 12$ $\mathrm{V}$, Inverter $12 \mathrm{~V}$ to $150 \mathrm{Watt} / 220 \mathrm{~V}$ ), $3 \mathrm{~s} / \mathrm{d} 6$ unit lampu jenis CFL 5 watt/220 V, Kabel Modul ke PBU, 2 x 2,5 mm, NYYHY, Kabel Instalasi lampu, 2 x 2,5 mm, NYM Penyangga Modul dan Tiang Penyangga

Metode yang digunakan dalam penelitian ini adalah metode eksperimen dan deskriptif. Eksperimen yaitu daya luaran sel surya diukur di bawah kondisi buatan (artificial condition) dimana kondisi variabel posisi penempatan (sudut absorbsi) dari sel surya terhadap bumi diubah bervariasi sesuai dengan sejumlah data yang dibutuhkan. Metode diskriftif yaitu variabel yang diteliti terdiri dari variabel suhu, iluminasi radiasi sinar matahari dan kelembaban diukur sebagaimana adanya berdasarkan variasi dari sejumlah waktu yang dibutuhkan (Nazir 2003). Pengukuran dilakukan dari bulan Mei sampai dengan bulan Juni 2011 bertempat di lokasi di Jln. Damai I Soverdi Oebufu Kupang. Teknik pengumpulan data dilakukan dengan pengukuran menggunakan peralatan ukur seperti AVO meter digital, thermometer digital, lux meter, higrometer, hasil-hasil pengukuran kemudian dimasukkan dalam tabel. Langkah awal sebelum dilakukannya pengukuran variabel parameter lingkungan didahului dengan pembangunan fisik PLTS tersebut dilengkapi dengan pemasangan instalasi. Kemudian setelah keseluruhan bangunan fisik pembangkit listrik tenaga surya mikro ini diselesaikan baru dilakukan pengujian dan pengukuran parameter yang dibutuhkan sebagai berikut:

- Pengukuran varibel arus keluaran sel surya dalam satuan Amper (A) dan tegangan keluaran dengan satuan Volt (V) untuk mendapatkan daya keluaran PLTS (P) dengan satuan Watt yang dirubah ke dalam bentuk energi dalam satuan Watt hour (Wh) disebut sebagai variabel terikat $\mathrm{Y}$ diukur dengan menggunakan AVO meter digital dilakukan dengan teknik penyambungan short circuit dan open circuit dengan keluaran positif dan negatif PLTS (keluaran dc).

- Pengukuran suhu keliling sel surya dalam satuan derajat celcius $\left({ }^{\circ} \mathrm{C}\right)$ yang disebut variabel bebas $\mathrm{X}_{1}$, parameter ini diukur dengan menggunakan thermometer digital dengan cara meletakkan sensor suhu diatas permukaan modul PLTS.

- Pengukuran iluminasi radiasi sinar matahari dalam satuan Lux (Lx) yang disebut sebagai variabel bebas $X_{2}$. Pengukuran parameter ini dilakukan dengan cara meletakkan lux meter (merek delorenzo) tersebut di atas modul PLTS.

- Pengukuran kelembaban udara dalam persen (\%) yang disebut sebagai variabel bebas $\mathrm{X}_{3}$ menggunakan higrometer, yang diletakkan berdekatan dengan modul PLTS yang digunakan.

- Pengukuran sudut penempatan posisi modul sel surya terhadap bumi yang dirubah bervariasi sesuai dengan kebutuhan data sebagai sample dalam derajat, yang disebut sebagai variabel $\mathrm{X}_{4}$. Parameter ini diukur dengan menggunakan busur dan kompas untuk menentukan kedudukan posisi derajat busur lintang.

Teknik analisis data yang digunakan adalah sebagai berikut: Analisis pengaruh parameter lingkungan (suhu, iluminasi radiasi sinar matahari dan kelembaban) terhadap luaran energi PLTS dianalisis dengan menggunakan analisis regresi berganda (Supranto, 2000). Analisis pengaruh letak posisi penempatan modul sel surya terhadap besarnya luaran energi yang dihasilkan PLTS dianalisis dengan menggunakan analisis varian (anova) (Sudjana, 2002).

Variabel yang diamati dalam penelitian ini adalah daya keluaran sel surya dalam satuan Watt (W) yang disebut sebagai variabel terikat Y, kemudian dirubah ke bentuk Energi (KWh), suhu disekeliling sel surya dalam satuan derajat celcius $\left({ }^{\circ} \mathrm{C}\right)$ yang disebut variabel bebas $\mathrm{X}_{1}$, 
iluminasi radiasi sinar matahari dalam satuan Lux (Lx) yang disebut sebagai variabel bebas $\mathrm{X}_{2}$, kelembaban udara pada permukaan sel surya dalam satuan $\%$ disebut sebagai variabel

\section{HASIL DAN PEMBAHASAN}

\subsection{Analisis Pengaruh Parameter} Lingkungan Terhadap Luaran Energi PLTS

Dugaan sementara (hipotesis) bahwa ada pengaruh parameter lingkungan (suhu, iluminasi radiasi sinar matahari dan kelembaban) terhadap luaran energi yang dihasilkan PLTS yang dianalisis dengan bebas $\mathrm{X}_{3}$, Sudut penempatan posisi modul sel surya terhadap bumi yang dirubah bervariasi sesuai dengan kebutuhan data sebagai sample dalam derajat, yang disebut sebagai variabel $\mathrm{X}_{4}$. menggunakan analisis regresi. Analisis pengaruh parameter lingkungan terhadap luaran energi PLTS mengambil data pengukuran pada pagi hari jam 09.Wita, siang hari jam 12.00 Wita dan sore hari jam 15 Wita, dengan posisi penempatan modul berkedudukan pada sudut $\varphi=90^{\circ}$. Data pengukuran disajikan pada Tabel 3.1.

Tabel 3.1 Hasil pengukuran suhu, iluminasi, kelembaban dan luaran energi PLTS

\begin{tabular}{|c|c|c|c|c|c|c|c|c|c|c|c|c|}
\hline \multirow[t]{2}{*}{ No. } & \multicolumn{4}{|c|}{ Jam 09 Wita } & \multicolumn{4}{|c|}{ Jam 12 Wita } & \multicolumn{4}{|c|}{ Jam 15 Wita } \\
\hline & $\begin{array}{c}\mathbf{E} \\
(\mathbf{W h})\end{array}$ & $\begin{array}{l}\mathrm{S} \\
(\mathbf{C})\end{array}$ & $\begin{array}{c}\mathbf{I r} \\
(\mathbf{L u x})\end{array}$ & $\begin{array}{c}K \\
(\%)\end{array}$ & $\begin{array}{c}\mathbf{E} \\
(\mathbf{W h})\end{array}$ & $\begin{array}{l}\mathrm{S} \\
(\mathbf{C})\end{array}$ & $\begin{array}{c}\mathbf{I r} \\
(\mathbf{L u x})\end{array}$ & $\begin{array}{c}\mathbf{K} \\
(\%)\end{array}$ & $\begin{array}{c}\mathbf{E} \\
(\mathbf{W h})\end{array}$ & $\begin{array}{c}\mathbf{S} \\
(\mathbf{C})\end{array}$ & $\begin{array}{c}\mathbf{I r} \\
(\mathbf{L u x})\end{array}$ & $\underset{(\%)}{\mathbf{K}}$ \\
\hline 1 & 36 & 30 & 27100 & 62 & 64 & 31 & 49500 & 53 & 31 & 30 & 23400 & 60 \\
\hline 2 & 33 & 28 & 24900 & 65 & 64 & 32 & 49000 & 51 & 35 & 32 & 26300 & 65 \\
\hline 3 & 35 & 29 & 26300 & 63 & 60 & 32 & 46400 & 57 & 23 & 30 & 17500 & 62 \\
\hline 4 & 30 & 25 & 22700 & 68 & 58 & 35 & 45000 & 59 & 22 & 31 & 16900 & 64 \\
\hline 5 & 30 & 25 & 22900 & 68 & 57 & 35 & 45000 & 60 & 22 & 31 & 16900 & 63 \\
\hline 6 & 20 & 23 & 15700 & 78 & 18 & 27 & 13900 & 60 & 12 & 27 & 9500 & 71 \\
\hline 7 & 33 & 25 & 25600 & 64 & 13 & 27 & 10600 & 61 & 4 & 27 & 3500 & 84 \\
\hline 8 & 22 & 23 & 17100 & 76 & 58 & 35 & 44700 & 59 & 45 & 33 & 34500 & 61 \\
\hline 9 & 37 & 32 & 28500 & 60 & 58 & 35 & 44700 & 44 & 45 & 33 & 34500 & 50 \\
\hline 10 & 39 & 35 & 29700 & 54 & 57 & 34 & 44000 & 49 & 44 & 33 & 33600 & 62 \\
\hline 11 & 38 & 32 & 28900 & 58 & 56 & 34 & 43600 & 53 & 43 & 33 & 32700 & 56 \\
\hline 12 & 39 & 33 & 29700 & 56 & 60 & 33 & 46500 & 42 & 43 & 33 & 32700 & 52 \\
\hline 13 & 38 & 30 & 28600 & 59 & 60 & 34 & 46600 & 50 & 35 & 29 & 26500 & 51 \\
\hline 14 & 37 & 30 & 27900 & 61 & 58 & 37 & 45000 & 49 & 33 & 30 & 26300 & 53 \\
\hline 15 & 36 & 30 & 27100 & 62 & 58 & 34 & 44800 & 50 & 22 & 33 & 16500 & 53 \\
\hline 16 & 35 & 32 & 26300 & 59 & 61 & 37 & 46100 & 54 & 39 & 33 & 29700 & 66 \\
\hline 17 & 34 & 30 & 26300 & 63 & 58 & 37 & 44200 & 51 & 39 & 33 & 29700 & 56 \\
\hline 18 & 36 & 31 & 27900 & 61 & 60 & 36 & 45800 & 49 & 50 & 34 & 38100 & 56 \\
\hline 19 & 39 & 33 & 30000 & 58 & 58 & 37 & 44200 & 49 & 50 & 34 & 38100 & 49 \\
\hline 20 & 37 & 33 & 28700 & 56 & 60 & 36 & 45800 & 47 & 37 & 33 & 28300 & 53 \\
\hline 21 & 38 & 33 & 28900 & 56 & 59 & 38 & 45100 & 47 & 37 & 33 & 28100 & 44 \\
\hline 22 & 39 & 34 & 29700 & 54 & 61 & 38 & 46200 & 50 & 50 & 34 & 37900 & 50 \\
\hline 23 & 38 & 33 & 28900 & 55 & 61 & 35 & 45800 & 48 & 36 & 32 & 27500 & 48 \\
\hline 24 & 37 & 31 & 27900 & 61 & 60 & 35 & 45500 & 55 & 49 & 33 & 37500 & 54 \\
\hline 25 & 36 & 31 & 27900 & 61 & 59 & 36 & 45300 & 51 & 31 & 33 & 23400 & 51 \\
\hline 26 & 38 & 32 & 29700 & 57 & 60 & 36 & 45300 & 54 & 31 & 33 & 23400 & 52 \\
\hline 27 & 38 & 32 & 28500 & 60 & 59 & 37 & 44700 & 50 & 44 & 33 & 33500 & 50 \\
\hline 28 & 40 & 33 & 29700 & 58 & 59 & 37 & 44900 & 48 & 36 & 34 & 27500 & 59 \\
\hline 29 & 27 & 25 & 20600 & 71 & 58 & 36 & 44300 & 57 & 42 & 33 & 31900 & 55 \\
\hline 30 & 12 & 23 & 9900 & 90 & 59 & 32 & 44800 & 58 & 20 & 28 & 16400 & 69 \\
\hline 31 & 21 & 25 & 17000 & 76 & 60 & 32 & 45800 & 67 & 17 & 30 & 14400 & 73 \\
\hline
\end{tabular}

Keterangan: E = Luaran energi; $\mathrm{S}=\mathrm{Suhu}$;Ir = Iluminasi radiasi sinar matahari; $\mathrm{K}=$ Kelembaban 
Tabel 3.2 Koefisien regresi suhu, iluminsi kelembaban terhadap luaran energi pada pagi hari

\begin{tabular}{clcccccc} 
Model & & \multicolumn{2}{c}{ Unstandardized Coefficients } & Standardized Coefficients & $\mathrm{t}$ & Sig. \\
& & $\mathrm{B}$ & Std. Error & Beta & \\
\hline 1 & (Constant) & .718 & 6.845 & & .917 & .105 \\
& Suhu & -.084 & .058 & -.045 & -1.439 & .162 & .000 \\
& Iluminasi & .001 & .000 & 1.027 & -.011 & -.148 & .883 \\
\hline
\end{tabular}

a Dependent Variable: Energi

Hasil analisis yang diperlihatkan pada Tabel 3.2. menunjukkan bahwa pada pagi hari:

1. Suhu tidak berpengaruh terhadap luaran energi PLTS $($ Sig. $=0.162>0.05)$

2. Iluminasi radiasi sinar matahari sangat berpengaruh terhadap luaran energi PLTS $($ Sig. $=0.000<0.05)$
3. Kelembaban tidak berpengaruh terhadap luaran Energi PLTS (Sig. $=0.883>0.05$ )

Dari tabel koefisien regresi tersebut dapat dibentuk model regresi yaitu:

$\mathrm{Y}=0.718+0.001 \mathrm{X}_{2}$

Jika $\mathrm{X}_{2}$ ( Iluminasi) bertambah 1 Lux maka Y (luaran energi) akan bertambah $0.001 \mathrm{Wh}$

Tabel 3.3 Koefisien regresi suhu, iluminsi kelembaban terhadap luaran energi pada siang hari

\begin{tabular}{|c|c|c|c|c|c|c|}
\hline \multirow[t]{2}{*}{ Model } & & \multicolumn{2}{|c|}{ Unstandardized Coefficients } & \multirow{2}{*}{$\begin{array}{c}\text { Standardized Coefficients } \\
\text { Beta }\end{array}$} & \multirow[t]{2}{*}{$t$} & \multirow[t]{2}{*}{ Sig. } \\
\hline & & $\mathrm{B}$ & Std. Error & & & \\
\hline \multirow[t]{4}{*}{1} & (Constant) & -3.691 & 1.994 & & -1.851 & .075 \\
\hline & Suhu & .121 & .047 & .030 & 2.574 & .016 \\
\hline & Iluminasi & .001 & .000 & .979 & 88.980 & .000 \\
\hline & Kelembaban & .000 & .019 & .000 & -.002 & .998 \\
\hline \multirow[t]{3}{*}{2} & (Constant) & -3.695 & 1.181 & & -3.129 & .004 \\
\hline & Suhu & .121 & .043 & .030 & 2.790 & .009 \\
\hline & Iluminasi & .001 & .000 & .979 & 90.906 & .000 \\
\hline
\end{tabular}

a Dependent Variable: Energi

Hasil analisis yang diperlihatkan pada Tabel 3.3. menunjukkan bahwa pada siang hari:

1. Suhu berpengaruh terhadap luaran energi PLTS $($ Sig. $=0.016<0.05)$

2. Iluminasi radiasi sinar matahari sangat berpengaruh terhadap luaran energi PLTS (Sig. $=0.000<0.05)$

3. Kelembaban tidak berpengaruh terhadap luaran PLTS $($ Sig. $=0.998>$ 0.05)

Dari tabel koefisien regresi tersebut dapat dibentuk model regresi yaitu:
$\mathrm{Y}=-3.695+0.121 \mathrm{X}_{1}+0.001 \mathrm{X}_{2}$

Jika $\mathrm{X}_{1}$ (Suhu) bertambah 1 derajat maka $\mathrm{Y}$ (luaran energi PLTS) akan bertambah 0.121 Wh dengan asumsi $X_{2}$ konstan. Jika $X_{2}$ (Iluminasi radiasi sinar matahari) bertambah 1 Lux maka Y (luaran energi) akan bertambah 0.001 Wh dengan asumsi $\mathrm{X}_{1}$ constan. 
Tabel 3.4 Koefisien regresi suhu, iluminsi kelembaban terhadap luaran energi sore hari

\begin{tabular}{clccccc}
\multirow{2}{*}{ Model } & \multicolumn{2}{c}{ Unstandardized Coefficients } & Standardized Coefficients & $t$ & Sig. \\
& \multicolumn{7}{c}{ B } & Std. Error & Beta & & \\
\hline 1 & (Constant) & -3.350 & 2.459 & & -1.362 & .184 \\
& Suhu & .125 & .072 & .021 & 1.728 & .095 \\
& Iluminasi & .001 & .000 & .977 & 76.682 & .000 \\
& Kelembaban & -.010 & .014 & -.007 & -.693 & .494 \\
& (Constant) & -4.434 & 1.879 & & -2.360 & .025 \\
& Suhu & .138 & .069 & .024 & 2.000 & .055 \\
& Iluminasi & .001 & .000 & .980 & 82.805 & .000 \\
\hline
\end{tabular}

Hasil analisis yang diperlihatkan pada Tabel 3.4 menunjukkan bahwa pada sore hari:

1. Suhu tidak berpengaruh terhadap luaran energi PLTS $($ Sig. $=0.095>0.05$ ).

2. Iluminasi radiasi sinar matahari sangat berpengaruh terhadap luaran energi PLTS (Sig. $=0.000<0.05$ ).

3. Kelembaban tidak berpengaruh terhadap luaran PLTS (Sig. $=0.494>$ $0.05)$.

Dari tabel koefisien regresi tersebut dapat dibentuk model regresi yaitu:

$\mathrm{Y}=-3.35+0.001 \mathrm{X}_{2}$

Jika $\mathrm{X}_{2}$ (Iluminasi) bertambah 1 Lux maka $\mathrm{Y}$ (luaran energi) akan bertambah $0.001 \mathrm{Wh}$.

Pada pagi hari suhu tidak berpengaruh terhadap luaran energi PLTS, artinya pancaran radiasi sinar matahari akan menembus udara dengan suhu lingkungan pada permukaan PLTS pagi hari yang tidak menjadi penghalang, sehingga iluminasi radiasi sinar matahari akan mengenai modul PLTS tersebut, sehingga luaran energi yang dibangkitkan PLTS tidak terpengaruh oleh suhu. Sebaliknya pancaran sinar mataharilah yang mengakibatkan suhu lingkungan di sekitar modul tersebut menjadi berangsur naik. Jika cuaca mendung, pancaran sinar matahari melemah suhu lingkungan pada permukaan modul PLTS juga menjadi rendah.

Kadir (1990), mengungkapkan bahwa besarnya arus listrik atau tenaga listrik yang diperoleh tergatung dari energi cahaya atau iluminasi radiasi sinar matahari yang mencapai sel-sel silicon (modul PLTS) dan tergantung juga dari luas permukaan modul tersebut. Dari hasil analisis yang dilakukan ungkapan dari Kadir tersebut dapat diterima dimana iluminasi radiasi sinar matahari sangat mendominasi dalam mempengaruhi luaran energi pada pagi, siang dan sore hari. kuat pancaran sinar matahari akan mengakibatkan permukaan dari modul PLTS tersebut dapat menerima dan menyerap energi yang jauh lebih tinggi, artinya fluktuasi kuat pancaran radiasi sinar matahari yang mengenai modul PLTS sangat berpengaruh, karena makin besar iluminasi radiasi sinar matahari maka luaran energi PLTS tersebut akan semakin besar.

Berdasarkan analisis yang dilakukan bahwa kelembaban udara tidak berpengaruh terhadap luaran energi, hal ini berarti bahwa walaupun kondisi udara pada lingkungan dimana ditempatkan PLTS tersebut lembab pada saat mata hari memancarkan sinarnya, pancaran radiasi sinar matahari tersebut tidak dapat di halangi oleh kelembaban. Kelembaban akan berkurang jika pancaran sinar matahari optimum.

Jika dikaji lebih jauh ungkapan Kadir (1990), maka dari analisis yang dilakukan jika pada pagi hari suhu tidak berpengaruh terhadap luaran energi PLTS dan pada siang hari suhu berpengaruh terhadap luaran energi pada PLTS. Disini jelas terlihat bahwa suhu pada siang hari dipengaruhi baik tegangan maupun arus listrik. Dengan demikian luaran energi juga dapat dipengaruhi oleh komponen arus dan tegangan 
yang keluar dari PLTS tersebut. Artinya dengan terpengaruhnya luaran energi akibat suhu pada siang hari berarti dapat dikatakan bahwa kekuatan pancaran sinar mataharilah yang

\subsection{Analisis Pengaruh Posisi Penempatan Modul Terhadap Luaran Energi PLTS}

Dugaan sementara (hipotesis) bahwa terdapat pengaruh letak posisi penempatan modul sel surya terhadap besarnya luaran energi yang dihasilkan PLTS dianalisis dengan menggunakan analisis varian (anova). Pengaruh letak posisi penempatan modul (sudut $\varphi)$ terhadap luaran energi PLTS (E) dengan menggunakan data pengukuran pada pagi (jam mengakibatkan suhu naik, dengan demikian seolah-olah suhu yang dapat mempengaruhi luaran energi.

09 Wita), siang hari jam (12.00 Wita) dan pada sore (jam 15 Wita), posisi penempatan modul pada sudut $\varphi=10^{\circ}, 20^{\circ}, 30^{\circ}, 40^{\circ}, 50^{\circ}, 60^{\circ}, 70^{\circ}$, $80^{\circ}, 90^{\circ}, 100^{\circ}, 110^{\circ}, 120^{\circ}$. Hasil pengolahan data dengan analisis varian (anova) pada pagi (jam 09 Wita) menggunakan program SPSS dalam bentuk grafik seperti pada Gambar 3.1, 3.2 dan 3.3 (Wijaya 2010).

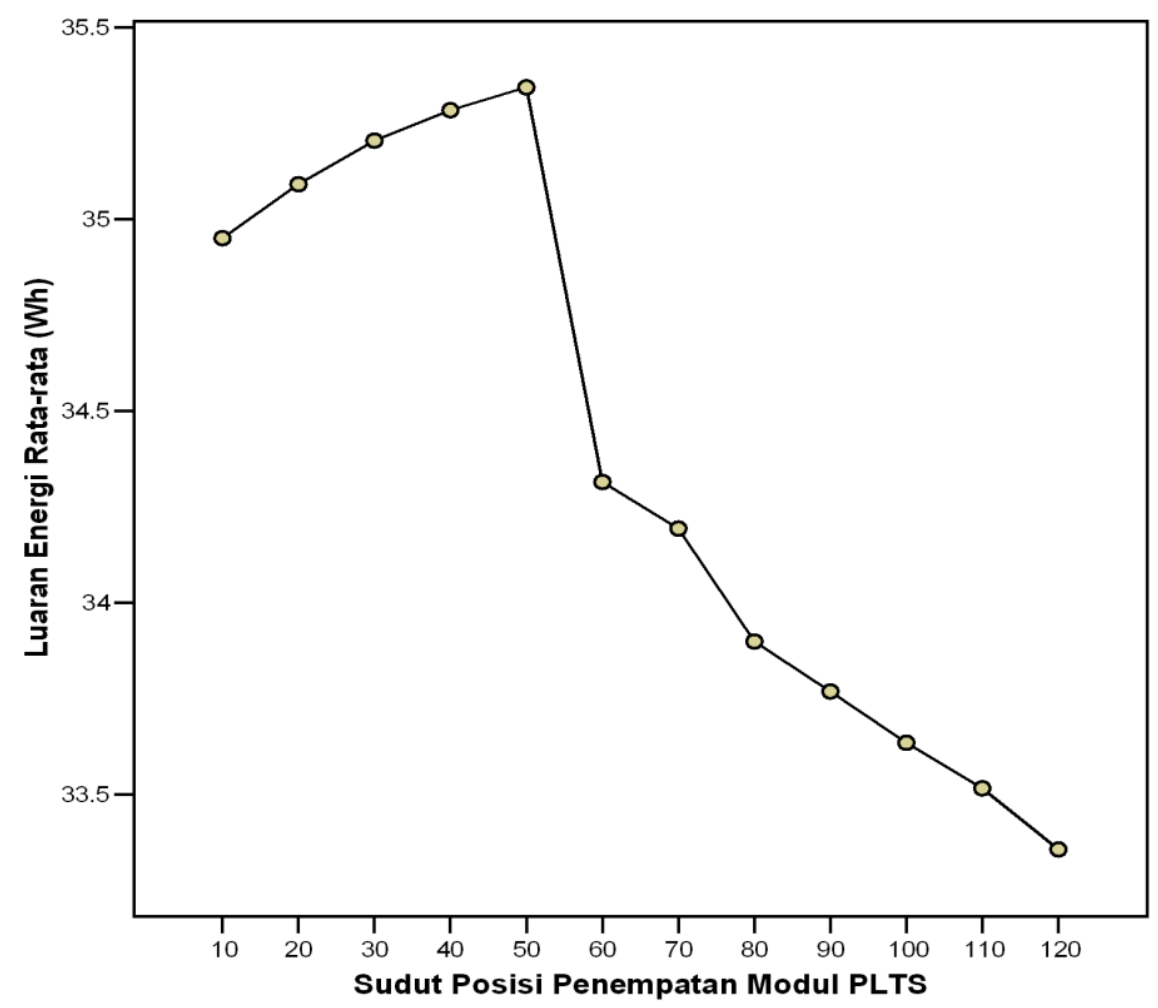

Gambar 3.1 Perubahan luaran energi akibat perubahan posisi penempatan modul pada pagi hari hasil one way anova

Kurva perubahan luaran energi rata-rata (Y) akibat perubahan posisi penempatan modul $(\varphi)$ hasil one way ANOVA Gambar 3.1 Jelas terlihat bahwa luaran energi rata-rata maksimum berada pada $35.34 \mathrm{Wh}$ yang terletak pada sudut posisi penempatan modul berada pada $\varphi=50^{\circ}$, dengan demikian penempatan modul PLTS posisi $\varphi=50^{\circ}$ dengan bumi pada pagi hari akan menghasilkan luaran energi maksimum. 


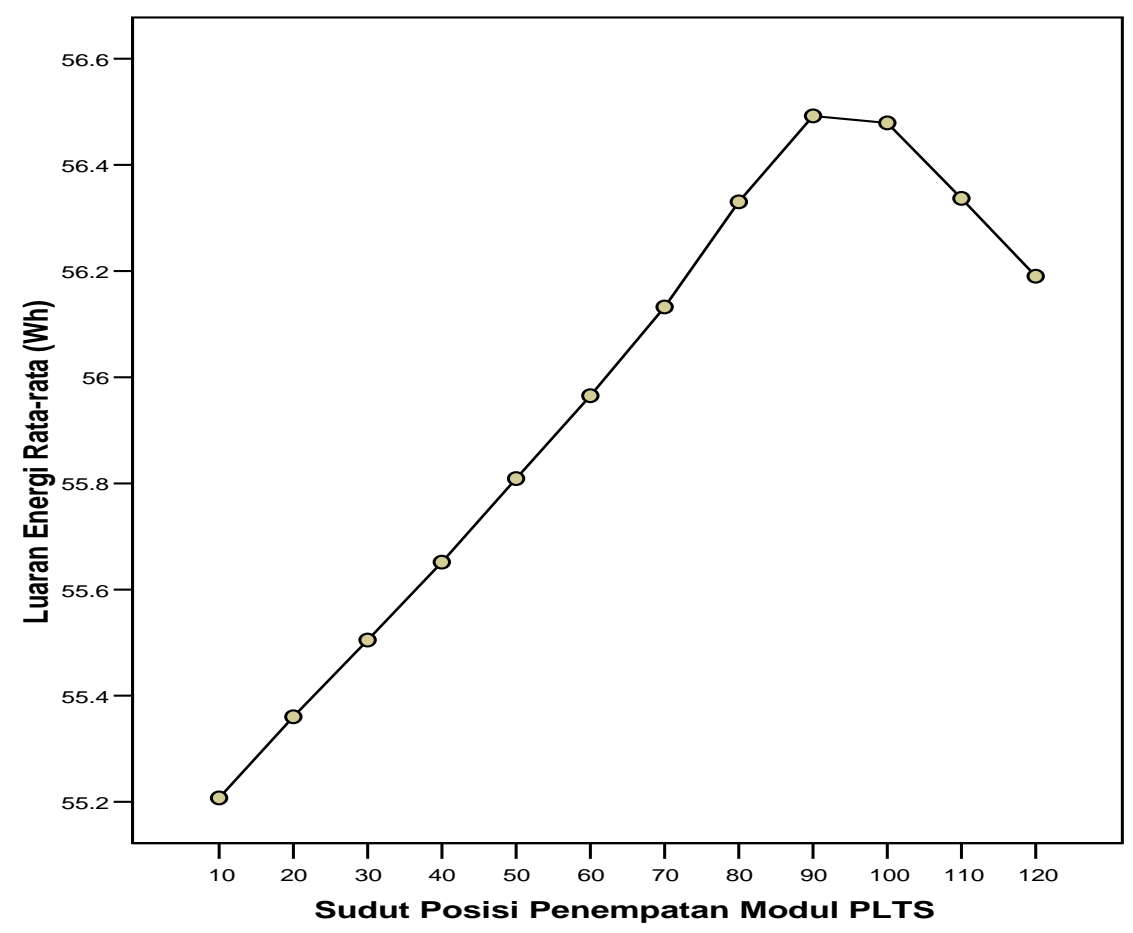

Gambar 3.2 Perubahan luaran energi akibat perubahan posisi penempatan modul pada siang hari hasil one way anova

Kurva perubahan luaran energi rata-rata (Y) akibat perubahan posisi penempatan modul $(\varphi)$ hasil one way ANOVA Gambar 3.2 jelas terlihat bahwa luaran energi rata-rata maksimum berada pada 56.49 Wh yang terletak pada sudut posisi penempatan modul berada pada $\varphi=90^{\circ}$, dengan demikian penempatan modul PLTS tegak lurus dengan bumi pada siang hari akan menghasilkan luaran energi maksimum.
Kurva perubahan luaran energi rata-rata (Y) akibat perubahan posisi penempatan modul $(\varphi)$ hasil one way ANOVA Gambar 3.3 jelas terlihat bahwa luaran energi rata-rata maksimum berada pada $34.60 \mathrm{Wh}$ yang terletak pada sudut posisi penempatan modul pada $\varphi=$ $100^{\circ}$, dengan demikian penempatan modul PLTS $\varphi=100^{\circ}$ bumi pada sore hari akan menghasilkan luaran energi maksimum. 


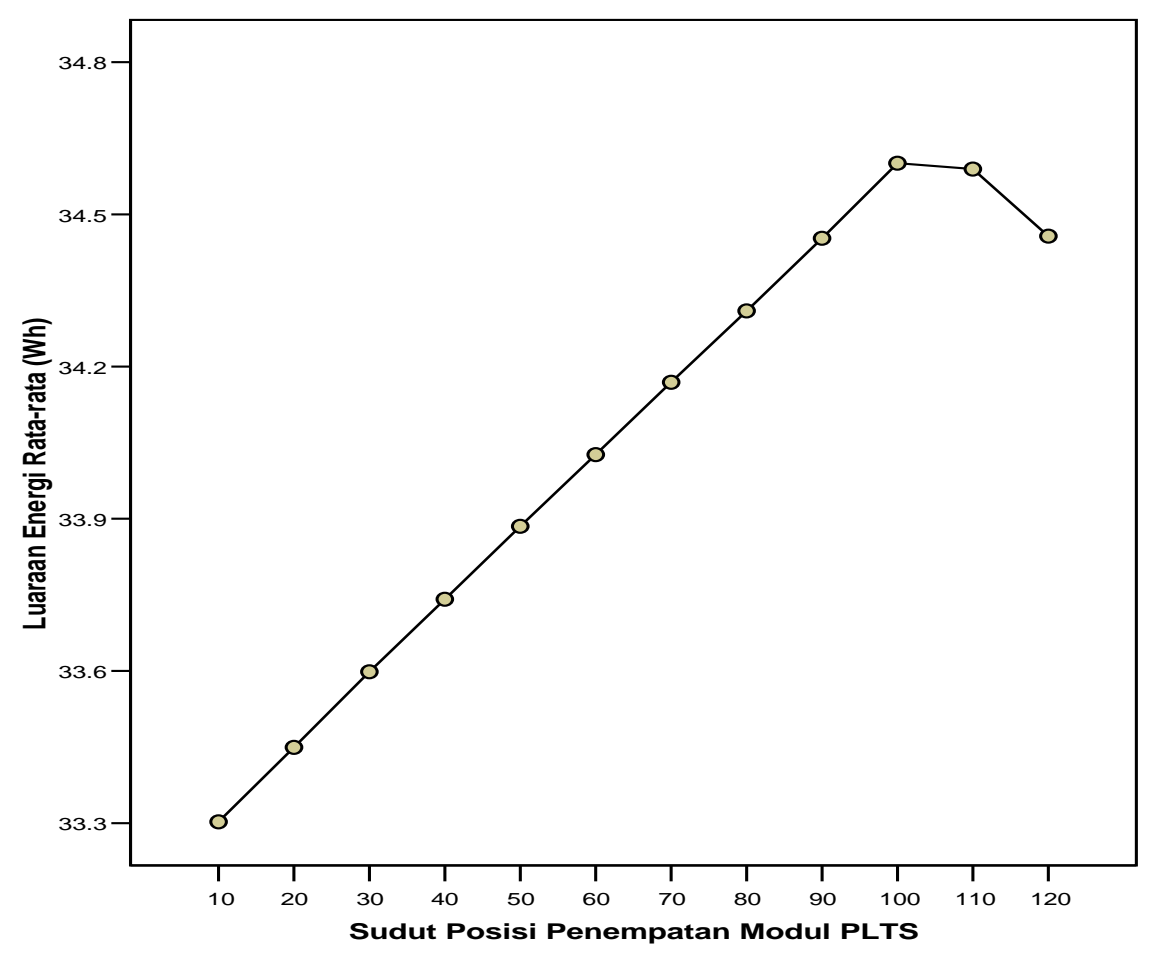

Gambar 3.3 Perubahan luaran energi akibat perubahan posisi penempatan modul pada sore hari hasil one way anova

\section{KESIMPULAN DAN SARAN 4.1. Kesimpulan}

Pada pagi, siang dan sore hari Iluminasi radiasi sinar matahari berpengaruh terhadap luaran energi pada PLTS, Jika Iluminasi bertambah 1 Lux maka luaran energi akan bertambah 0.001 Wh dengan asumsi suhu konstan. Pada siang hari Suhu berpengaruh terhadap luaran energi pada PLTS, Jika Suhu bertambah 1 derajat maka luaran energi PLTS akan bertambah 0.121 Wh dengan asumsi iluminasi radiasi sinar matahari konstan. Pada pagi, siang maupun sore hari kelembaban tidak berpengaruh terhadap luaran energi pada PLTS.

Terdapat pengaruh letak posisi penempatan modul sel surya terhadap luaran energi dimana pada pagi hari luaran energi ratarata maksimum berada pada 35.34 Wh yang terletak pada sudut posisi penempatan modul pada $\varphi=50^{\circ}$, penempatan modul PLTS posisi $\varphi=50^{\circ}$ dengan bumi pada pagi hari akan menghasilkan luaran energi maksimum. Pada siang hari luaran energi rata-rata maksimum berada pada $56.49 \mathrm{Wh}$ yang terletak pada sudut posisi penempatan modul berada pada $\varphi=90^{\circ}$. Penempatan modul PLTS tegak lurus dengan bumi pada siang hari akan menghasilkan luaran energi maksimum. Pada sore hari luaran energi rata-rata maksimum berada pada $34.60 \mathrm{Wh}$ yang terletak pada sudut posisi penempatan modul berada pada $\varphi=100^{\circ}$, Penempatan modul PLTS $\varphi=100^{\circ}$ terhadap bumi pada sore hari akan menghasilkan luaran energi maksimum.

\subsection{Saran}

Kepada para pengguna PLTS, sebaiknya agar penggunaan PLTS tersebut benar-benar optimum dalam memproduksi energi, supanya pemasangan modul sel surya yang digunakan ditempatkan tegak lurus $\left(90^{\circ}\right)$ terhadap permukaan bumi.

Iluminasi radiasi sinar matahari sangat mempengaruhi luaran energi PLTS, untuk itu 
penempatan modul PLTS sebaiknya ditempatkan menghadap matahari atau tegak lurus terhadap bumi. Suhu lingkungan akan menurun dan kelembaban akan semakin besar jika cuaca mendung dan lingkungan dimana modul PLTS ditempatkan jika dihalangi oleh pohon dan tanaman lainnya, sudah barang tentu iluminasi radiasi sinar matahari semakin kecil mengenai modul PLTS, untuk itu sebaiknya pohon dan tanaman lainnya yang menghalangi sinar matahari mengenai modul PLTS agar dapat ditebang.

Untuk pencapaian optimalisasi luaran energi PLTS pengembangan lebih lanjut dapat merancang dudukan modul sel surya menggunakan motor stepler mengikuti arah matahari.

\section{DAFTAR PUSTAKA}

Djojonegoro (1992), Pengembangan Energi Terbarukan Sebagai Energi Aditif di Indonesia, Diakses 2 Mei 2011 pada Elektro Online and Indosat Net Http:// Www.Elektroindonesia.Com/Elektro/En ergi

Kadir (1990), Energi, Universitas Indonesia, Jakarta

Nazir Moh (2003), Metode Penelitian, Ghalia Indonesia, Jakarta

SHS (2010), Solar Home System, Vicca, Surabaya

Sinlae Y., Benu F.L., Sampeallo A.S.,Kellen P.B. (2004), Rencana Umum Ketenagalistrikan Daerah Provinsi Nusa Tenggara Timur, Universitas Nusa Cendana, Kupang

Soemarwoto O. (2004), Ekologi Lingkungan Hidup dan Pembangunan, Djambatan Jakarta

Supranto J. (2000), Statistik, Teori Dan Aplikasi, Erlangga Jakarta

Sudjana (2002), Metoda Statistik, Tarsito Bandung

Walery Wenas Wilson (2003), Teknologi Sel Surya, diakses 4 Mei 2011 pada Http:// Www.Elektroindonesia.Com/Elektro/En ergi3.html
Wijaya Tony (2010), Cepat Menguasai SPSS 19, Cahaya Atma, Yogjakarta 